\title{
THE THERAPEUTIC JOURNEY OF PEOPLE WITH VENOUS ULCERS IN OUTPATIENT CARE ${ }^{1}$
}

\author{
Dalva Cezar da Silva², Maria de Lourdes Denardin Budón, Maria Denise Schimith ${ }^{4}$, Vânia Lúcia Durgante ${ }^{5}$, \\ Salete de Jesus Souza Rizzatti ${ }^{6}$, Lúcia Beatriz Ressel ${ }^{7}$
}

\footnotetext{
${ }^{1}$ Paper derived from the thesis - The therapeutic journey of people with venous ulcer receiving outpatient care: contributions to nursing, presented to the Programa de Pós-Graduação em Enfermagem at the Universidade Federal de Santa Maria (UFSM), in 2013.

${ }^{2}$ Doctoral student at the Programa de Pós-Graduação em Enfermagem at Universidade Federal do Rio Grande do Norte (UFRN). RN, Nursing Department at UFSM. Santa Maria, Rio Grande do Sul, Brasil. E-mail: dalvacezarsilva@yahoo.com.br

${ }^{3}$ Ph.D. in Nursing. Associate Professor, Departamento de Enfermagem and Programa de Pós-Graduação em Enfermagem at UFSM. Santa Maria, Rio Grande do Sul, Brazil. E-mail: lourdesdenardin@gmail.com

${ }^{4}$ Ph.D. in Sciences. Professor, Departamento de Enfermagem at UFSM. Santa Maria, Rio Grande do Sul, Brazil. Email: ma.denise2011@gmail.com

${ }^{5}$ M.Sc. in Nursing. RN, outpatient service at the Hospital Universitário at Santa Maria (HUSM). Santa Maria, Rio Grande do Sul, Brazil. E-mail: vaniadurgante@yahoo.com.br

${ }^{6}$ M.Sc. in Nursing. RN, Home Care Service of HUSM. Santa Maria, Rio Grande do Sul, Brazil. E-mail: saleterizzatti@gmail.com ${ }^{7}$ Ph.D. in Nursing. Associate Professor, Departamento de Enfermagem and Programa de Pós-Graduação em Enfermagem at UFSM. Santa Maria, Rio Grande do Sul, Brazil. E-mail: lbressel208@yahoo.com.br
}

\begin{abstract}
This study's objective was to describe the therapeutic journey of people with venous ulcers receiving outpatient care. This qualitative study was conducted from January to February of 2013 using semi-structured interviews with 14 people with venous ulcers cared for by an outpatient clinic at a public hospital in Rio Grande do Sul, Brazil. The following categories emerged from the content analysis: search within the Popular Sector; search within the Folk Sector; and search within the Professional Sector. Based on how the individuals identified the origin of the venous ulcer and were influenced by their sociocultural contexts, people implemented different care practices and had to frequently review their journey in the search for healing. The conclusion is that the therapeutic journey was composed of various paths in which the Popular and Professional Sectors strongly influenced the experience of people with venous ulcers. DESCRIPTORS: Nursing. Varicose ulcer. Ambulatory care.
\end{abstract}

\section{ITINERÁRIO TERAPÊUTICO DE PESSOAS COM ÚLCERA VENOSA EM ASSISTÊNCIA AMBULATORIAL}

RESUMO: Objetivou-se descrever o itinerário terapêutico de pessoas com úlcera venosa em assistência ambulatorial. Pesquisa qualitativa, desenvolvida no período de janeiro a fevereiro de 2013, por meio da entrevista semiestruturada com 14 pessoas com úlcera venosa, no serviço ambulatorial de um hospital público no Rio Grande do Sul, Brasil. Após a análise de conteúdo dos dados, elaboraram-se as categorias: busca ao Setor Popular, busca ao Setor Folk e busca ao Setor Profissional. A partir de como é identificada a origem da úlcera venosa e da influência do contexto sociocultural, as pessoas realizaram diferentes práticas de cuidados com frequentes revisões do percurso, em busca da cicatrização da lesão. Conclui-se que o itinerário terapêutico mostrou-se constituído por uma pluralidade de caminhos, em que os setores popular e profissional influenciaram intensamente a experiência da pessoa que convive com a úlcera venosa. DESCRITORES: Enfermagem. Úlcera varicosa. Assistência ambulatorial.

\section{ITINERARIO TERAPÉUTICO DE PERSONAS CON ÚLCERA VENOSA EN CONSULTA EXTERNA}

RESUMEN: Se objetivó describir el itinerario terapéutico de personas con úlceras venosas en consulta externa. Investigación cualitativa desarrollada en el período de enero a febrero de 2013, a través de entrevistas semi-estructuradas con 14 personas con úlceras venosas en una clínica de consulta externa de un hospital público en Rio Grande do Sul, Brasil. Después del análisis de contenido de los datos se elaboraron las categorías: búsqueda del Sector Popular, búsqueda del Sector Folk y búsqueda del Sector Profesional. A partir de cómo es identificado el origen de la úlcera venosa y la influencia del contexto sociocultural, las personas realizan diferente prácticas de cuidado con frecuentes revisiones en busca de la curación de la lesión. Se concluye que el itinerario terapéutico está constituido por una pluralidad de caminos, donde los sectores populares y profesionales influyen fuertemente en la experiencia de la persona que vive úlcera venosa.

DESCRIPTORES: Enfermería. Úlcera varicosa. Atención ambulatoria. 


\section{INTRODUCTION}

Various issues can influence a search for health care, whether it is the supply of formal health care services or sociocultural aspects of the context in which health care practices take place. The path a person takes in the search for treatment and cure for a disease, from its diagnosis up to its resolution, is called in the anthropology of health in a therapeutic journey. ${ }^{1}$

Knowledge concerning this therapeutic journey can facilitate the understanding of health workers concerning the context of patients and thereby identify strengths and weaknesses. Additionally, visualization of the repercussions of professional practice and other health care systems is usually facilitated. ${ }^{2}$

To explain one's journey and search for care, the concepts Explanatory Models and Health Care Systems developed by Kleinman play an important role in the literature. ${ }^{3}$ From this perspective, health, disease and care are part of a cultural system that involves the experience of symptoms, behavior models, decisions in regard to treatment and therapeutic practices, in addition to assessing the results. Hence, these elements are used to identify how people and the social environment consider health care delivery, which is internally composed of the interactions of three sectors: Popular, Folk and Professional. ${ }^{4}$

The Popular (sometimes denoted the Informal) Sector is represented by people close to the patient, such as family members, friends and neighbors, including the community, all kinds of activities and support provided by social networks. ${ }^{4}$

The Folk (sometimes denoted the Traditional) Sector is composed of recognized nonprofessional healers, that is, without official regulation. This sector include religious groups, spiritual healers, energy healers, chanters, and herbalists who provide care through manipulative treatments and healing rituals, among other means. These people hold the same cultural values from the community in which they live. Therefore, they provide explanations about the disease that are more easily understood by the social group. ${ }^{4}$

The Professional Sector comprises healthcare professionals from the official healthcare network. Biological aspects are usually a priority for these professionals, while psychosocial and cultural aspects are of secondary importance. Scientific medicine or traditional medicine, such as for the Chinese, is included in this sector. ${ }^{4}$
Each of these Sectors has their own way to explain and treat someone's lack of health with particular ways to interact during the therapeutic meeting. Effective communication among the Sectors is needed during the patient's coping process, as it enables exchange of different types of knowledge. ${ }^{5}$ Such communication also helps the identification of specificities of the case, including severity, availability and how appropriate the resources are in order to establish one's path in the search for healthcare. ${ }^{6}$

When nurses, members of the Professional Sector, focus on practices that contextualize popular knowledge and experiences, they enable a relationship of proximity for healthcare sectors and also allow for reflection, within their practice, on how the disease experience is being constructed by the patient ${ }^{5}$ and mediated by culture.

Based on the assumption that cultural aspects can influence the care provided to people with skin lesions, we opted to investigate the therapeutic journey of individuals with venous ulcers. This is the primary type of chronic ulcer of the lower limbs and present high levels of recurrence and chronicity. ${ }^{7}$

We highlight nursing care within the health delivery system provided to this population ${ }^{7}$ because it is essential to establish rapport when providing care to individuals with ulcers in order to identify their therapeutic journey from the lesion's onset to experiences and practices used in the attempt to find a cure. The purpose is to enhance care practices that are closer to the context of these people. ${ }^{8}$

Identification of the path taken in the search for healthcare and the difficulties faced while trying to access public health services enables perceiving the need to plan more efficacious healthcare actions, as individuals with venous ulcers are common in the routines of health services, such as in outpatient clinics' corridors and treatment rooms, due to the chronic nature of leg wounds and the difficulty of effectively treating such wounds. ${ }^{9}$

In this context, we ask: what is the therapeutic journey of people with venous ulcers receiving outpatient care? Hence, the objective was to describe the therapeutic journey of people with venous ulcers receiving outpatient care.

\section{METHOD}

This qualitative study was developed in the outpatient service of a public hospital in the inte- 
rior of Rio Grande do Sul (RS), Brazil. This setting was chosen because it is a university hospital, a reference center for secondary and tertiary care in the central region of RS and care is provided exclusively through the Brazilian Unified Health System (SUS).

A total of 14 people with venous ulcers participated in the study. Inclusion criteria were: having venous ulcers, receiving outpatient care and being monitored by service services in the period of data collection, and being 18 years old or older. Codes I1 to I14 were used to identify the participants, where the letter "I" stands for "interviewee" followed by the number that corresponds to the order in which the individuals were interviewed.

Data were collected from January to February of 2013 through semi-structured interviews conducted in the outpatient clinic in a room reserved for that purpose. The interviews addressed identification information, how the participants sought care and treatment for their ulcers, and how the search for care was performed in the Popular, Folk and Professional Sectors. These data enabled identifying personal, social and cultural factors of each participant, which influenced the therapeutic journey constructed from the onset of the venous ulcer.

Data were treated according to content analysis ${ }^{10}$ which is composed of three stages: pre-analysis, in which interviews are transcribed and empirical material is organized; exploration of the material, in which the empirical material was categorized and indicated the search in the Popular, Folk, and/ or Professional Sectors; treatment of results, inferences and interpretation, which linked empirical content with the theoretical framework.

The study was approved by the Institutional Review Board at the university with which it is associated (Protocol n. 23081.000145/2008-19). Ethical principles proposed by Resolution 196/96, National Council of Health were complied with. The participants signed Free and Terns of Informed Consent that clarified the study's objectives.

\section{RESULTS AND DISCUSSION}

We first present the interviewees' characterization and then the therapeutic journey of people with venous ulcers receiving outpatient care according to the following categories: Search within the Popular Sector; Search within the Folk Sector; and Search within the Professional Sector.
The 14 people with venous ulcers participating in the study were between 47 and 79 years of age and nine were women. Duration of the wound ranged from six months to 25 years; 13 participants had one wound and one had two wounds; ten experienced recurrences and four had wounds for the first time. In regard to comorbidities, three people reported Diabetes Mellitus (DM); two reported Systemic Hypertension (SH); two reported $\mathrm{DM}$ and $\mathrm{SH}$; one reported DM, SH and Chronic Renal Insufficiency; and six denied comorbidities.

\section{Search within the Popular Sector}

The path taken by the person with a venous ulcer began when changes in the integrity of skin were perceived. At home, care was based on values and beliefs. The individuals, however, had difficulty identifying the first signs as a situation that required professional care.

In the search for care in the Popular Sector, the participants mentioned the use of home remedies based on personal experience or persuaded by intense influence exerted by the family and neighbors. I'd put some ointment on it, at the time I'd put alcohol, you know this type of thing and carried on (I6); I wouldn't care, it was really small so I'd go to work. I always left it wrapped in a bandage, but instead of taking care of it, like putting on some medication for it to heal, I'd put nothing on it, so it tended to get bigger (I5).

The first signs were masked, as they were treated with home-alternative remedies, which ameliorated it somewhat, but did not solve the problem. Home remedies were the first care procedures used and the search for healthcare services was often initiated after these attempts. ${ }^{11}$

In order to decide who or what type of help to seek, the interviewees took into account the experiences of family members or neighbors who had already experienced a similar situation. The fact there were family members with venous ulcers influenced the search for care. My mother had it, she'd make some remedies at home (I4). This is a family thing, my grandma had it, my mother had it, and now we do, four out of six [siblings]. My sister [had an ulcer] for more than 30 years and it healed, it seems crazy, with ointment. My niece changed the dressing every day and her leg healed (I12).

The Popular Sector, here especially represented by the family, was the one that became most strongly involved with the context of the disease and care. Care provided by family members is the 
first therapeutic intervention implemented in different cultures. People consult beliefs and values regarding the disease to understand what is happening and to plan the care that will be provided. ${ }^{4}$

The search for care in the Popular Sector was marked by a plurality of practices. Care practices included cleaning and sterilization of the wound to avoid or minimize the risk of infection and complications and to facilitate the healing process. $I^{\prime} d$ wash it with water and soap. Some said it was good, others said it was not, recommending only to wash around it (I7); Many times I woudn't even go to the health unit. I'd buy hydrogen peroxide myself or anything proper to clean it, and saline solution, which is the main thing to clean it well. When there was no saline solution, I'd boil water and let it cool to clean it (I10).

Hence, even though people did not have solutions or medications recommended by the professional health care system, they attempted the most varied forms and substances to clean their wounds based on folk-empirical evidence.

Therefore, popular knowledge and practices, even if different from scientific knowledge, are used to provide care to meet individuals' needs. ${ }^{8}$

Among the diverse treatments used in the Popular Sector, there was also the use of sugar and self-medication. People taught me to put sugar because it is good to heal. Sugar hurts, you can't stand it (I6); I'd put ointment at home, dexamethasone, so I went to the doctor. He freaked out because I used this ointment, so I said: 'I don't know, that's why we came here'. It's for allergy and I used it on the wound as soon as it appeared (I4).

The person with the wound concluded that the care orientation provided by someone from his network was not appropriate for his health condition. Another issue that emerged as a common practice was self-medication, which may anticipate or even delay the search for a healthcare professional.

Medicinal teas and plants were identified as resources used in treatment. Sometimes I'd use some medication, a lot of people teach us to use home medicine, wash it with tea (I7); I'd use aloe vera because I was told it was very good to use on it, wash and put it there (I10).

Family members and neighbors recommend teas and generally provide the plants. This recommendation is based on successful experiences when using plants as a medicinal resource. ${ }^{1}$ In addition to cultural issues, economic hardship and lack of access to health professionals and services contribute to the popular use of plants in the care of wounds. ${ }^{8}$

Resting was also a practice recommended by the Popular Sector, which the interviewees recognized as benificial to the healing process of venous ulcers. Resting helps. Because it's an open wound, as you walk it opens even more, when you stand up. So, the more you rest, the better (I1); The most important practice is resting, the more you rest, the faster it heals (I3).

Reference to resting was recurrent in the reports, which may have been part of the health professionals' instructions, but is also a practice recommended within the Popular Sector. Hence, it is a reinterpretation concerning the professional knowledge put into practice by the person with a venous ulcer.

It was confirmed that people linked beliefs and practices concerning health and diseases existing in the cultural context with a reinterpretation of professional practices. Health professionals also constitute sources of information, knowledge and build upon already existing beliefs. ${ }^{12}$

The path to be followed was identified according to the assessment of the situation of the venous ulcer: maintain care currently implemented or seek another solution to heal the lesion. $I^{\prime} d$ do the dressing at home but it got like this [...] very large, it got larger and larger, I don't remember which doctor said that these dressings have to be done by a specialized professional (I12).

This study's results show that when people used care practices from the Popular Sector, they experienced complications and their wounds were aggravated, requiring a search in the Professional and/or Folk Sectors. It does not mean, however, that care provided by the Popular Sector was disregarded. In both Western and Eastern societies, $70 \%$ to $90 \%$ of diseases are treated in this sector. It is in this sector that decisions regarding how, when and which sector should be consulted are made, that is, what is the therapeutic journey one has to follow. ${ }^{4}$

\section{Search within the Folk Sector}

In the Folk Sector we identified that faith, prayers and spiritual support helped the individuals with venous ulcers to reprogram their lives. Nonetheless, according to some reports products, used during ritualistic prayers said over the wounds sometimes would not help or even aggravate the situation. 
Folk practices included prayers, communion and Umbanda*, as the following excerpts show: I've never asked for "benzeduras" [ritualistic prayers], only prayers to get better and people pray for me too, they are my brothers and sisters of my church (I13); The only tea I've taken was arnica tea. I took it because it is anti-inflammatory and I went to [...] an Umbanda temple (I8); I went there one day, there was this caboclo* there, they did it [...] once, twice, three times (I14).

Visits to the Umbanda temple, to spiritual healers, and prayers were among the main spiritual practices experienced as treatment and care; when people perceived something different was happening, they searched for explanations. In this sense, these practices help in times of tension, comforting and alleviating symptoms.

The manifestation of spirituality through a belief in a Higher Being, who provides comfort in times of anguish and distress, appeared as a strategy used to cope with the disease. ${ }^{13}$ Religious practices are searched to acquire emotional support and spiritual comfort. Religious support and faith is necessary regardless of someone's socioeconomic status. ${ }^{8}$

Benzeduras or ritualistic prayers are emphasized among the Folk practices, especially using green leafs, water, oil and coal, tapioca flour, and dry grass, among other substances and products. These substances were used in the ritualistic prayers and some report that they were applied on the wound, while others report these substances were used only to wash the wound.

The Folk Sector was searched before the Professional Sector in order to solve the problem. I sought these "saravá" [term used in Afro-Brazilian religions that means salute] things, visited spiritual healers, I sought this sort of things. Then I started visiting the health unit, sometimes had to go to the hospital (I5).

An issue that influenced the search for care in the Folk Sector was the proximity of people who performed the practices in this sector. There were family members who were "healers". I went one day. The "caboclo" called me there, it's my son who channels [the spiritual entity]. He did something with honey and I don't know what they put in it, but they applied it to the wound and put a bandage because I was wearing the boot [Unna boot]. There was honey and stuff - I don't what it was. I only know there was black stuff in it and there was cachaça $a^{* * *}$ too (I14).

The search within the Folk Sector together with the treatment provided within the Professional Sector is an attempt to enhance the healing process. The interviewee, even though undergoing treatment with the Unna boot, sought care in the Folk Sector.

In another situation, care practices provided by the Folk Sector, while not solving the problem, caused complications and resulted in the need to search for professional care. Such a situation was identified when practices that compromised the health status of the individual with a venous ulcer was used. I'd mix a lot of things, I was not Evangelical at the time. All that "benzedura", lots of things I'd apply there and it didn't help at all, it actually worsened even my condition more. It was my sisters-in-law, one day I got really sick and they applied some stuff on my foot that removed the skin. They got scared and took me to the emergency room here in downtown (I5).

A lack of solution was verified with the practices applied within the Folk Sector and these practices were actually considered to be related to the worsening of the wound. In the case of people with venous ulcers, the lesion's chronic nature and recurrence can aggravate the patient's socioeconomic situation and hinder mobility, some of the impediments to accessing treatment. ${ }^{14}$

One of the interviewees was born into a remnant Quilombo ${ }^{* * * *}$ community and we believe he may have been influenced initially to seek healing resources from the Folk Sector. Popular knowledge regarding the treatment of diseases in the context of an Afro-Brazilian community is strongly influenced by the system of beliefs or by the members of religious congregations. Religious belief is recurrent in the sense that it explains diseases and care needed. ${ }^{15}$

\section{Search within the Professional Sector}

The Professional Sector emphasized that individuals should seek health services and medical care. People with venous ulcers initially sought primary health care, often without achieving a

\footnotetext{
* T.N. Afro-Brazilian religion.

** T.N. Spiritual entities.

*** T.N. Brazilian alchololic beverage.

**** A Brazilian hinterland settlement founded by people of African origin.
} 
solution to the problem because the origin of their difficulties was not always properly addressed. Hence, the patients were referred to specialized services for effective diagnosis and treatment. In this journey, individuals faced difficult access to services, as well as a lack of specialized professionals in their region or city, sometimes finding it necessary to commute to other specialized healthcare units. We verified that they also sought professional care in private health services.

Professional care was sought in situations where vascular damage was aggravated, such as in the case of thrombosis. A diagnosis was reached in the consultation with a professional who clarified the difficulty in healing the wound, a process that would be simple and rapid but, which became complex and chronic. I always had this purple spot; after a while it opened up as if it was a mosquito bite. We thought it was a little bruise that you put some ointment on and it heals, but my foot became increasingly swollen and the leg also swollen. Then I went to the doctor from [a city $66.2 \mathrm{~km}$ away from the study setting] and I told him, I complained about my foot, my foot was like [shows how swollen it was], and it was thrombosis. The doctor said 'it is a lack of circulation, varicose related', and referred me. His clinic was a private one. So I went there and he gave me medication for blood circulation and I took the medication and he treated me (I6).

Private services stood out as a resource used within the Professional Sector before the public health service was sought. Additionally, in some situations, private services were used as a way to access public services, characterizing inappropriate access to the public health service.

Similarly, the use of private services and/or health insurance/health plans became new forms to access the health services. Private services were identified as being responsible for referring patients to hospitalization in the SUS. We confirmed that people accessed the system using different means, such as private and public services in the different levels of care complexity. ${ }^{16}$

We also verified a delayed search for health services, which presented important gaps regarding care delivery. These gaps include difficult access and the professional qualification of the staff to encourage and maintain closer and effective contact with the population under (or without) their care. ${ }^{17}$

The search for professional care is characterized by a constant search for different types of services and replacing the health care service from one city to another. The first place I went to, when this problem begun, was the healthcare unit at [city A that is $63.4 \mathrm{~km}$ away from the outpatient clinic under study] and they referred me to another physician at [city B, $70.8 \mathrm{~km}$ away from the study setting], then he sent me here. In [city A] there are not many resources and they sent me to [city B], and the physician thought it would be a good idea to refer me to Dr. C's office, who referred me [...] The consultation was private, I saw him one day and he gave me the papers and I came here the day after (I3).

The search for care took place in different health services and the individuals had difficulty solving the problems related to that. These individuals reported that they needed to act on their own and sought different health services to meet their needs. Hence, the strategies used to overcome the weakness of the health system included seeking a private service or even leaving the city where they lived to find a health service in another city. ${ }^{16}$

Another recurrent issue was the informal contacts used to initiate treatment in the outpatient service under study. People from the patients' circles of relationships and even family members were responsible for informally contacting the physician to initiate treatment. My daughter started working here and her co-workers told her 'perhaps you can arrange a consultation with the doctor for your mother' One day she talked to him and he gave her a paper to schedule one consultation. Then I started the treatment with him (I5).

People used various strategies to open up the doors of the system, in addition to learning some "social rules" currently used in the health services. When these individuals decided to seek medical attention, they sought third-party help or directly addressed the physician. ${ }^{18}$

In the face of this finding, we stress the need to review rules to access the service, establishing with the users new forms to enter the system. This means that the care model should continually adapt to the context in order to provide integral care. Hence, it is the health system that needs to adapt to the needs of its users (the weakest component in the system) and not the contrary. ${ }^{19}$

Establishing follow-up with the health professional was remarkable in the therapeutic journey of these individuals with venous ulcers. This care action was highlighted, however, because it was initiated in different health services, as the following excerpt shows: I visited the doctor right away. I kept going to the health unit and they would put that coal on for me (I4); I always sought medical 
care to take care of my wound. Before, it was done there [city of origin], then here, I started coming here every Tuesday (I14); the clothes I was wearing on the day this vein on my leg burst out became soaked with blood. So I came here to the hospital and the doctor did everything, gave me medication, and I saw other physicians (I12).

The first search for a physician may have been influenced by knowledge concerning the ulcer, because there were other people within the family with the same lesion and also because of the way it was initiated. Many different paths were taken, however, by the individuals with venous ulcers, who saw different physicians and visited different healthcare services according to their personal assessment of what they needed in regard to health service.

Therefore, issues related to health and disease needed to be analyzed with the remaining dimensions of social life. The choices or searches made by these people for care was influenced by their customs, beliefs and values, that is, by their cultures. These are the elements on which social actors constructed meanings for their actions and interactions. ${ }^{19}$

Additionally, the way healthcare supply was organized was not efficacious and limited possibilities of meeting these individuals' health needs. Many barriers were faced in the search for health services, such as difficulty in establishing a correct and timely diagnosis, while a fragmented view of service generated inadequate screening and referrals. ${ }^{20}$

Emergency Rooms and Health Care Units were services included in the patients' search. In the beginning I'd go to the hospital, then I went to a hospital that had an outpatient clinic and was nearby, and then they sent me to the unit. When I was pretty bad, I'd go to the emergency room, but they don't do dressings there, only give you medication. I saw it was very inflamed, very swollen, so I sought another service. [at the emergency room] they only would give me a prescription and sent me to the unit (I9); I went to the health unit, they looked at it and sent me to the hospital. At the hospital, the deal was something else, I stayed there for the dressings. After about 20 days I left the hospital and went home but had to undergo hemodialysis so I came back. Then the doctor said: 'You are staying.' - Doc why am I going to stay? 'Your wound is horrible' (I8).

The need for frequent hospitalizations was identified among the study's participants. Hospitalizations could have been avoided if their conditions had been stabilized with appropriate followup. In many cases, the hospitalization indicates failures in care delivery, which if well-conducted, could have interrupted this course before the individuals' health conditions had worsened. ${ }^{17}$

People with venous ulcers take many different paths seeking a solution to their health problems and, being true pilgrims, they are the ones who wander among health services.

Even though outpatient services have been expanded and primary health units have been established as the system's entrance door, the users of the SUS still prefer emergency rooms and hospitals to seek out medical care. ${ }^{18}$ Regardless of the level or type of service, the person seeking medical care must receive proper assistance. ${ }^{18}$

The individuals with venous ulcers sought the health services expecting to solve their problem but did not always receive the care they needed. We identified a lack of proper diagnoses and laboratory exams, restricted access to medical angiologists, topical treatment being restricted to the change of dressings, no compressive therapy being prescribed, treatments were discontinued and lesions were not re-assessed, which reflect an absence of an comprehensive referral and counter-referral system and collaboration among the different levels of care within SUS. ${ }^{21-22}$

In regard to professional care, we note that the way information was shared, the way patients were approached and how their knowledge was valued are some aspects that need to be improved. It is important that health workers be sensitive to the context of patients. Hence, identifying the reality of patients, their origins and values may result in an efficient and efficacious approach. ${ }^{6}$

The search for care simultaneously occured in more than one Sector: We do everything. Take the medication prescribed by the doctors too, antibiotics, anti-allergic drugs, because sometimes you can't stand the itch, it's hard. Then someone says that something is good, I go and do that too. I have no idea of everything we use, sometimes we think it was one thing but it was another [that helped to improve]. I'm already taking the medication prescribed by the doctors and washing with tea; I fear mixing too many things (I10).

This diversity of resources may be an explanation for doubts and uncertainty among people with venous ulcers in regard to the result of the treatment. It is also important to consider the cultural context and view of the world of those with wounds in order to maintain a dialogical relationship seeking coherent care. Care transcends the treatment of wounds and an integral view of the individual enables the identification of needs 
and particularities, especially because a wound changes the routines of people and can emotionally and physiologically affect them., ${ }^{7,23}$

In this sense, there is a need for professional interventions to go beyond the wound and include assessment and treatment focused on the person as a complex and integral being so that the lack of knowledge regarding care practices and the needs that permeate the search for health services is overcome and incorporates the various health determinants and conditioning factors.

\section{CONCLUSIONS}

The search for care on the part of people with venous ulcers was influenced by what they deemed to be the origin of the wound or contact with people who had already experienced it within their families. In the initial phase, there was an emphasis on the family and network relationships, the Popular Sector, so that care was provided at home. In addition to the Popular Sector, a search in the Folk Sector was intensified by religious influences. In the Professional Sector, a search for different health services and medical appointments were reported.

In this search, which did not always result in a solution, tension was reported due to the organization of a universal public health care network, which did not provide appropriate and equal care within the public subsystem, with other models of self-care identified in the study. We identified people, often times solitary in their search for the care to which they are entitled, which is provided by law and should ensure integral care, but which still presents important weaknesses.

This paper is expected to contribute to the understanding of the process undergone by people with disease and their search for care. In this sense, there are gaps in the health system as a whole and also in regard to health workers. Alternative practices should be sought to qualify care delivery in order to provide care that is appropriate to the real needs of people with venous ulcers.

The diversity of resources sought by people with venous ulcers reflects ineffectual care practices that resulted in the patients frequently reviewing their journey in the search for healing. From this perspective, new paths were traced and the identification of how this process occurred can help health workers understand the sociocultural context in which they are inserted and broaden the possibilities of care-planning.
Practices originating in the Popular and Professional Sectors predominated, a result that was perhaps influenced by the fact that interviews were held with individuals with venous ulcers receiving care in an outpatient clinic. Hence, there is a need for further studies in the nursing field to deepen this topic, a tool that can optimize the actions of nurses in monitoring and caring for people with venous ulcers.

\section{REFERENCES}

1. Mattosinho MMS, Silva DMGV. Itinerário terapêutico do adolescente com diabetes mellitus tipo I e seus familiares. Rev Latino-Am Enfermagem. 2007; 15(6):1113-9.

2. Maliska ICA, Padilha MICS. AIDS: a experiência da doença e a construção do itinerário terapêutico. Rev Eletr Enferm [online]. 2007 [acesso 2013 Jun 16]; 9(3):687-99. Disponível em: http:/ / www.fen.ufg.br/ revista/v9/n3/v9n3a09.htm

3. Cabral ALLV, Vianna ALL, Martinez-Hemáez A, Andrade EIG, Cherchiglia ML. Itinerários terapêuticos: o estado da arte da produção científica no Brasil. Ciênc Saúde Coletiva. 2011; 16(11):4433-42.

4. Kleinman A. Patients and Healers in the context of culture. Berkley (US): University of California; 1980.

5. Garcia RP, Budó MLD, Oliveira SG, Beuter M, Girardon-Perlini NMO. Setores de cuidado à saúde e sua inter-relação na assistência domiciliar ao doente crônico. Esc Anna Nery. 2012; 16(2):270-6.

6. Amaral RFC, Souza T, Melo TAP, Ramos FRS. Itinerário terapêutico no cuidado mãe-filho: interfaces entre a cultura e biomedicina. Rev Rene. 2012; 13(1):85-93.

7. Sant'Ana SMSC, Bachion MM, Santos QR, Nunes CAB, Malaquias SG, Oliveira BGRB. Úlceras venosas: caracterização clínica e tratamento em usuários atendidos em rede ambulatorial. Rev Bras Enferm. 2012; 65(4):637-44.

8. Alcoforado CLGC, Santo FHE. Saberes e práticas dos clientes com feridas: um estudo de caso no município de Cruzeiro do Sul, Acre. Reme - Rev Min Enferm. 2012; 16(1):11-7.

9. Angélico RC P, Oliveira AKA, Silva DDN, Vasconcelos QLDQ, Costa I KF, Torres GV. Sociodemographic profile, clinical and health of people with venous ulcers treated at a university hospital. J Nurs UFPE online [online]. 2012 [acesso 2014 Abr 20]; 6(1):62-8. Disponível em: http://www.ufpe. $\mathrm{br} /$ revistaenfermagem/index.php/revista/article/ view/2100/pdf_759

10. Bardin L. Análise de conteúdo. São Paulo (SP): Edições 70; 2011.

11. Budó MLD, Resta DG, Denardin JM, Ressel LB, Borges ZN. Práticas de cuidado em relação à dor: a 
cultura e as alternativas populares. Esc Anna Nery. 2008; 12(1):90-6.

12. Rosa LM, Búrigo T, Radünz V. Itinerário terapêutico da pessoa com diagnóstico de câncer: cuidado com a alimentação. Rev enferm UERJ. 2011;19(3):463-7.

13. Rocha LS, Beuter M, Neves ET, Leite MT, Brondani CM, Perlini NMOG. O cuidado de si de idosos que convivem com câncer em tratamento ambulatorial. Texto Contexto Enferm [online]. 2014 [acesso 201426 abr.]; 23(1): 29-37. Disponível em: http:// www.scielo.br/pdf/tce/v23n1/pt_0104-0707tce-23-01-00029.pdf

14. Korelo RIG, Valderramas S, Ternoski B, Medeiros DS, Andres LF. Aplicação da microcorrente como recurso para tratamento de úlceras venosas: um estudo piloto. Rev Latino-Am. Enfermagem. 2012 [acesso 2013 abril 18]; 20(4): [08 telas]. Disponível em: http://www.scielo.br/pdf/rlae/v20n4/pt_16.pdf

15. Silveira CL, Budó MLD, Ressel LB, Oliveira SG, Simon BS. Apoio social como possibilidade de sobrevivência: percepção de cuidadores familiares em uma comunidade remanescente de quilombos. Ciênc Cuid Saúde. 2011; 10(3):585-92.

16. Camacho TP, Barboza MCN, Roese A.Trajetórias percorridas por usuários com doença cardiovascular até ainternação hospitalar. Rev Enferm UFSM [online]. 2013 [acesso 2014 Abr 26]; 3(3):509-17. Disponível em: http://cascavel.ufsm.br/revistas/ojs-2.2.2/ index.php/reufsm/article/view/8233/pdf

17. Oliveira K, Veronez M, Marques CDC, Higarashi $\mathrm{IH}$, Marcon SS. Itinerário percorrido pelas famílias de crianças internadas em um hospital escola. Rev Bras Enferm. 2014; 67(1): 36-42.

18. Oliveira LH; Mattos RA; Souza AIS. Cidadãos peregrinos: os "usuários" do SUS e os significados de sua demanda a prontos-socorros e hospitais no contexto de um processo de reorientação do modelo assistencial. Ciênc Saúde Coletiva. 2009; 14(5):1929-38.

19. Langdon EJ, Wiik FB. Antropologia, saúde e doença: uma introdução ao conceito de cultura aplicado às ciências da saúde. Rev. Latino-Am. Enfermagem [online]. 2010 [acesso 2014 Abr 26]; 18(3):[09 telas]. Disponível em: http://www.scielo.br/pdf/rlae/ v18n3/pt_23

20. Visentin A, Lenardt MH. O itinerário terapêutico: história oral de idosos com câncer. Acta Paul Enferm. 2010; 23(4):486-92.

21. Dantas DV, Torres GV, Nóbrega WG, Macedo EAB, Costa IKF, Melo GSM, et al. Assistance to patients with venous ulcers based on protocols: literature review in electronic databases. Rev Enferm UFPE [online]. 2010 [acesso 2013 Abr 18]; 4(Esp 4):194450. Disponível em: http://www.revista.ufpe.br/ revistaenfermagem/index.php/revista/article/ viewArticle/1481

22. Nóbrega WG, Melo GSM, Costa IKF, Dantas DV, Macedo EAB, Torres GV. Changes in patients' quality of life with venous ulcers treated at the outpatient clinic of a university hospital in Natal City, Brazil. Rev Enferm UFPE [online]. 2011 [acesso 2013 Abr 14]; 5(2):220-7. Disponível em: http:// www.revista.ufpe.br/revistaenfermagem/index. $\mathrm{php} /$ revista/article/viewArticle/1478

23. Waidman MAP, Pagliarini MA, Rocha SC, Correa JL, Brischiliari A, Marcon SS. O cotidiano do indivíduo com ferida crônica e sua saúde mental. Texto Contexto Enferm [online]. 2011 [acesso 2013 Jun 26]; 20(4):691-9. Disponível em: http:/ / www.scielo.br/ pdf/tce/v20n4/07.pdf 